\title{
Latino Identity in U.S. Society
}

\author{
Valerie M. Mendoza
}
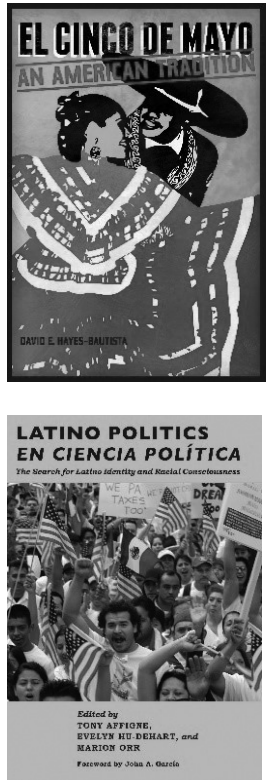
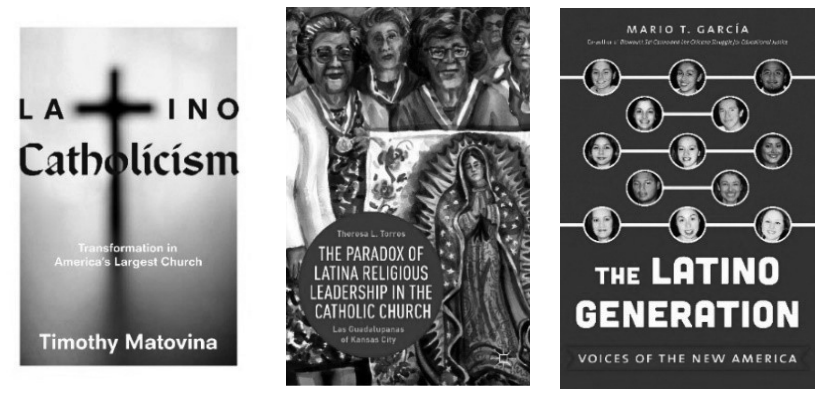

EL CINCO DE MAYO: An American Tradition. By David Hayes-Bautista. Berkeley: University of California Press. 2012.

LATINO CATHOLICISM: Transformation in America's Largest Church. By Timothy Matovina. Princeton, NJ: Princeton University Press. 2012.

THE PARADOX OF LATINA RELIGIOUS LEADERSHIP IN THE CATHOLIC CHURCH: Las Guadalupanas of Kansas City. By Theresa L. Torres. New York, NY: Palgrave Macmillan. 2013.

THE LATINO GENERATION: Voices of the New America. By Mario T. García. Chapel Hill: University of North Carolina Press. 2014. 
LATINO POLITICS EN CIENCIA POLÍTICA: The Search for Latino Identity and Racial Consciousness. Edited by Tony Affigne, Evelyn Hu-DeHart, and Marion Orr. New York: New York University Press. 2014.

According to the 2010 census, over fifty million Latinos reported living in the U.S. (16 percent of the U.S. population). ${ }^{1}$ This represents a 43 percent increase over the number given in the 2000 census. As a result of their growing numbers, Latinos settled outside traditional receiving areas with the South and Midwest seeing the largest increase (57 percent and 43 percent, respectively). The population growth can partially be attributed to the birth rate and partially to immigration. The latter category promises to remain a hot button political issue, especially in the 2016 Presidential election. Major candidates in both parties seek to woo this important demographic and corporate America has also taken notice of Latinos and is trying to figure out how to market effectively to this heterogeneous group with enormous purchasing power. Latino influence continues to grow numerically, which is evidenced in scholarship as well as politics and popular culture.

Since the 1990s scholarly works featuring Latinos as subject matter have flourished. Indeed, in the last couple years alone academics have produced a broad range of works on topics from festivals to religion to politics. Each of the works in this essay depicts Latinos as creating identity and community for themselves in U.S. society. Latinos do this by claiming space as active agents and by changing or influencing U. S. culture through various mediums - the Catholic Church, politics, and holiday celebrations. Indeed, Latinos exert agency by taking issues into their own hands. Each of these books either argues that Latinos act as a collective group to further their agenda despite their differences, or they discuss Latinos as a collective group, thus focusing on panethnic identity and negating differences between them.

In his work about Cinco de Mayo, David Hayes-Bautista asks the question "Why is Cinco de Mayo [which celebrates the Mexican victory over the French in the first battle of Puebla in 1862] widely celebrated in the United States and not in Mexico?" He concludes that the holiday is a product of the U.S. Civil War and French imperialism in Mexico, and that it was created and celebrated by Latinos in California from diverse backgrounds (Californios, Mexicans, South Americans). This disparate group united in a show of panethnic identity to celebrate freedom and democracy and they created a public memory of the Cinco de Mayo victory. While this historical work focuses mainly on California, Hayes-Bautista shows that Latinos came together and formed a society by building upon Californio society, and in doing so they created a space for themselves by celebrating the first battle of Puebla. This celebration eventually morphed into a nationwide American holiday of a Mexican event. Indeed, the celebration of present-day Cinco de Mayo has completely strayed from its original purpose of commemorating the victory at Puebla and serves as an American drinking holiday heavily marketed to Anglo Americans by beer companies. 
Originally, however, the victory proved to be a source of pride and symbolized the triumph of the Mexican spirit over imperialism and tyranny-very American notions, as the author notes. Through the use of Spanish-language newspapers from throughout the state, the author shows how Latinos gathered together in public spaces to commemorate the Cinco de Mayo victory in cities large and small. Celebrations occurred in areas traditionally thought of as Mexican (Los Angeles and San Francisco), and also in large numbers in the California interior of the Gold Rush region, where miners from South America resided. Latinos thus claimed space and asserted their presence in California's public sphere by taking to the streets in spontaneous (and later planned) celebrations of the victory at Puebla.

Through the celebration of Cinco de Mayo, Hayes-Bautista shows how Latinos in California came together as a community and built a common identity despite originating from all over the world. He argues that these people of different nationalities became unified in part by language (Spanish), culture, Latino merchants, political interests, and especially the Spanish-language press. These common denominators overcame the divisions of race, class, and regional/ national identity. Instead they created a panethnic identity. Through these Cinco de Mayo celebrations Latinos in California influenced U.S. culture by coming together as a group and claiming public space.

One of the great strengths of the book is the way in which the author takes a seminal event in U.S. history - the Civil War - and squarely situates it in Latino history rather than the other way around. Instead of trying to place Latinos into American history via a historical event, Hayes-Bautista foregrounds the Latino experience and adds the Anglo perspective to it. In fact, despite the Civil War's centrality in the creation of Cinco de Mayo, the Anglo point of view is almost completely absent from the book. Instead he explains how in the minds of California's Latinos, the Civil War and the Mexican War against the French were linked by the Union and Juarez governments, with each fighting for freedom and liberty. Another strength of the book is its emphasis on transnationalism. El Cinco de Mayo clearly delineates the linkages between Mexico and Latinos in California in the creation of this public holiday, and also links the U.S. with Central and South America due to initial support of the miners from this region who lived in California at the time.

Hayes-Bautista clearly lays out the origins of this American holiday and outlines how the event changed from a public commemorative event to a holiday celebrated primarily by Mexicans and Mexican Americans. What is missing, and perhaps the subject for another book, is how the holiday came to be celebrated outside of California.

El Cinco de Mayo is the only work in this review essay that is a full-fledged history. The other books discussed in this review explore contemporary Latino communities. Two of these works view Latino lives through the lens of religion. The first, The Paradox of Latina Religious Leadership, examines a group of women involved in a religious society known as Las Guadalupanas, who take 
their name from Our Lady of Guadalupe. In contrast to Hayes-Bautista's use of newspapers, the author, Theresa Torres, takes an ethnographic approach that relies on interviews, participant observation, and archival materials. Like HayesBautista's work, this book also centers on a single place, but then expands the focus to include gender. In her book, Torres demonstrates how Latinas create identity and community in the Heartland.

Torres analyzes the Guadalupana Society of Kansas City, which she argues poses a paradox: despite the fact that women came together as Guadalupanas to use their collective power to prevent the closing of Our Lady of Guadalupe Church in Kansas City, Missouri, their power and agency were limited by both internal and external forces. ${ }^{2}$ After the crisis passed, the women once again became a subaltern group within the context of the church in part because they circumscribed their own power.

The book begins with a historical overview of the Mexican and MexicanAmerican community of Kansas City, and shows how one of the focal points of the community - particularly during the migration phase of the early twentieth century - was Our Lady of Guadalupe Church, which was established in the early 1920s. Membership in the church became a way for this othered group to claim a public space in Kansas City's landscape and served as a place of community, camaraderie, and refuge. When the Archdiocese of Kansas City announced the closing of the parish in the 1990s in order to save funds, the focal point of this community of color became threatened. Las Guadalupanas, a female religious society that had been around since the 1930s, lobbied the Archdiocese to keep the church open as a shrine. The two parties reached an agreement with very strict conditions, chief among them that the Guadalupanas would be responsible for the upkeep and funding of the shrine. The group rose to the challenge by holding fundraising events throughout the year and hosting the feast of Our Lady of Guadalupe at the shrine. By challenging an established power and succeeding in their endeavors, Torres argues, these women were able to demonstrate their agency. Also, in helping to reverse the archdiocese's decision, the women showed how Mexican Americans as a constituency influenced a major power in U.S. culture - the Catholic Church (a predominant theme in Timothy Matovina's work discussed below).

Thanks to the efforts of Las Guadalupanas the shrine continued to serve as a "cultural support system" (5) and as a space for enacting meaning (7) that connects the community to its ethnic identity. The strength of Torres's book lies in her oral interviews and analyses of society members, which demonstrates how women's faith, history, and agency interconnect with the shrine. However, Torres found that this agency only went so far. Collectively, Las Guadalupanas were "not willing to be activists, except, when it came to the very heart of their existence [as a group] which was to save their parish church in honor of Our Lady of Guadalupe" (128). In other words, their agency only extended to the project of saving this one public, religious space that had historic and contemporary 
meaning to them. In saving the church they also continued to claim a place in the public sphere.

Due to the demographic nature of Kansas City, Torres only discusses Mexicans and Mexican Americans, albeit of different generations, rather than discussing the Latino population as a whole as do the other works discussed here. However, in examining women of Mexican origin in a city away from the U.S.-Mexico border, Torres makes a significant contribution to Chicano Studies in particular. She shows that a vibrant Mexican community exists outside the southwestern United States and as such expands our current understanding of Mexicans and Mexican Americans. Additionally she adds to the sparse literature on the contemporary influence of Our Lady of Guadalupe, along with the work of Jeanette Rodriguez (Our Lady of Guadalupe: Faith and Empowerment Among Mexican-American Women, 1994).

In Latino Catholicism, Timothy Matovina takes on another aspect of Latino Catholics in the U.S., focusing on the ways in which the U.S. Catholic Church and Latinos mutually transform one another. His book contributes to the Catholic narrative by including Latinos, an often overlooked group despite the fact that they comprise over one third of U.S. Catholics and are widely heralded as the future of the Catholic Church in the U.S. Matovina has written an ambitious book that covers conquest to the present. The book explores the Church's response to U.S. Latinos and the exertion of Latino agency, which forced the Church to respond to their needs. Latino Catholicism, therefore, shows how Latinos created an identity for themselves in arguably the most influential religious institution in the country.

Latinos as a whole have the largest number of Catholic practitioners. At the same time, however, many are leaving the church in droves for evangelical Christianity, or are not actively practicing a religious faith at all. The Catholic Church and the media haven taken notice of this trend, with Time magazine dedicating a cover story to the issue. ${ }^{3}$ The large number of Latino constituents provides an opportunity for the Catholic Church to revitalize its base, but the fact that one in four Latinos consider themselves former Catholics poses a huge challenge for the Catholic leadership, according to Matovina. ${ }^{4}$

Matovina discusses how the Americanization paradigm used for previous groups of European immigrants was automatically applied to Latinos. The paradigm includes the establishment of immigrant churches, schools, and shrines. Two challenges in particular exist within this model. For one, each successive generation leaves the Church so that by the third or fourth generation immigrant churches tend to die out — one reason given for the closing of Our Lady of Guadalupe Church in Kansas City discussed by Torres. This paradigm, however, does not take into account the unique aspects of Latinos in the Church, such as the constant influx of new immigrants and the hemispheric nature of worship.

For well over a decade scholars have studied transnationalism, defined as the notion that for groups such as Latinos migration does not progress linearly from one country to another, but is a back and forth process between sending 
and receiving countries. Matovina applies this theory to religiosity. For example, migrants regularly send home remittances, some of which the sending community uses for church upkeep. Another transnational aspect of these migrant groups is that they often return home for baptisms and weddings, thus practicing their faiths in two countries and claiming public space in both. This hemispheric influence can also be found in liberation theology, which in the U.S. is currently demonstrated in the many Latino Catholic parishes that advocate for justice for immigrants. This was particularly salient in 2006 when congregations mobilized against the Sensenbrenner Bill, which proposed harsh penalties against those entering the country illegally and represents another way in which Latinos have influenced the church and literally claimed public space by taking to the streets (see chapter 7, "Public Catholicism").

While the Catholic leadership created what is known as the Hispanic Ministry to cater to Latinos, its effectiveness is largely a result of pressure exerted by Latino clergy and lay people. This phenomenon began with the Encuentro conferences in the 1970s that aimed to "develop a pastoral plan for the Hispanic American community" (76). While the first Encuentro was ad hoc, small, and organized by Latino clergy, the powers that be took notice, and the second Encuentro five years later was much bigger and included members of the Church hierarchy. The third Encuentro developed a National Pastoral Plan with the purpose of being "communitarian, evangelizing, and missionary; incarnate in the reality of the Hispanic people" (85). According to Matovina, the legacy of these conferences cannot be underestimated. They were instrumental in forming a Latino lay leadership and heightened recognition and respect of the Hispanic presence in the church (95). Today's outreach efforts are in fact indebted to the Encuentro era and they represent another powerful way that Latino clergy and the Latino presence have influenced the Catholic agenda in the U.S.

The lack of Latino clergy represents one of the main challenges of the socalled Hispanic ministry. The strength of Latino Catholics, however, lies in the fact that they count permanent deacons, women, and new immigrants as lay leaders, who, according to Matovina, "are the most abundant resource for Hispanic ministry" (145). Other ways Latino Catholics have taken charge of their religiosity and influenced the Church includes the apostolic movements, which the author asserts are the most significant way Latinos have influenced the internal dynamics of the Church. This charismatic style emphasizes a personal relationship with Christ and direct evangelization that had heretofore been absent from the traditional Church. This style of worship originated in Protestant churches and its adoption in Catholic worship represents a direct response by the Church to keep Latinos in the fold.

Matovina effectively demonstrates that the power of Latinos in the Church stems from their large numbers and their interrelated histories and interests. However, in doing this he conflates these groups, erases their distinctions, and describes Latinos in the Church as an undifferentiated group. Latino Catholi- 
cism ends with the Church's recognition that if it is to survive with the help of Latinos, it needs to find a way to minister effectively to the younger generation.

The younger generation of Latinos is the subject of Mario García's book The Latino Generation: Voices of the New America. García defines the Latino Generation as the children of recent immigrants from Mexico and Central America. Previously García had coined and defined the Immigrant Generation from 1910-1930, the Mexican American Generation who came of age during World War II; and the Chicano Generation, who advocated for civil rights in the 1960s and 1970s. The dubbing of the Latino Generation is García's "attempt to make some historical sense of the more contemporary changes affecting Latinos coming of age at the end of the twentieth century and the beginning of the new millennium" (6). The bulk of the book consists of testimonios by Latino students who attended the University of California at Santa Barbara (UCSB) where García teaches Chicano history. The oral histories were conducted between 2002 and 2010 and include thirteen students composed of ten females and three males of mostly Mexican backgrounds. Through these interviews García clearly shows how this new generation of Latinos have created communities and identities for themselves in U.S. society.

Arguably, this group of young people exerts great influence on the changing American landscape. In fact in Spring 2015, Target, Inc. announced that it would concentrate its marketing efforts on millennials and Latinos because these two groups represent the company's largest opportunities for growth. ${ }^{5}$ As both millennials and Latinos, the Latino Generation represents each of these interests. Indeed, President Obama has issued two executive orders that directly influence this demographic. ${ }^{6}$ As García himself notes, the history and culture of the United States cannot be appreciated without the story of Latinos; the Latino experience is the American experience (3).

García notes that one thing that distinguishes this group from other "generations" is that they are "less guarded about expressing their Latino identity" (29). One way members of the Latino Generation express their identities is through civil disobedience, which is a direct response to the surge in neo-nativism and anti-immigrant sentiment that this generation grew up with. Direct action - such as participating in protest marches and rallies, infiltrating detention centers, and challenging government policies by crossing the border and then trying to reenter the country without papers - is a hallmark of this generation. This group of young people has adopted previous civil rights tactics (such as "coming out" from the Gay rights movement), and taken them to the next level. As with other millennials, the Latino generation makes extensive use of technology such as social media and texting. For example, Twitter and Facebook are regularly used to rally support for those in detention and prevent their deportation. Groups such as Detention Watch and Immigrant Justice disseminate information about immigrants incarcerated in detention centers. This type of intervention has been highly successful and has resulted in several people being released from detention 
centers. Social media also allow the Latino Generation to feel more connected to one another and less isolated than previous generations. It represents a new type of "public space" that they have claimed. The growth of the Spanish-language mass media also facilitates this connection. ${ }^{7}$

These narratives offer a tremendous primary resource for scholars, as they humanize the children of immigrants and young immigrants themselves. One of the interesting finds of the testimonios is this group of young people's emphasis on their pan-Latino identities. As García comments, many reject or are ambivalent about the term Chicano despite the fact that all but one of his interviewees originates from Mexico. Since the 1960s, most young people of Mexican descent in California have traditionally identified as Chicano. However, as he notes, the Latino Generation see themselves as forging a "new mestizaje" in which "different Latino groups influence each other culturally" (30). This is due in large part to the fact that these immigrants' families come from countries other than Mexico. For example, García interviewed Amílcar Ramírez who is Afro-Latino and whose parents are from Honduras.

While these oral histories offer a tremendous resource, one is also left wanting more. The edited testimonios offer a wealth of information that allows the reader to come to his or her own conclusions, but their usefulness could have been enhanced with more analysis such as that provided in Torres's book. Also, García never acknowledges that these students are exceptional to begin with. They persevered and made it through a leaky educational pipeline, overcame language barriers in some cases, and excelled in their educational pursuits to be admitted into a highly competitive university. ${ }^{8}$ How would our understanding of the Latino Generation change if we included those who dropped out of high school or those who attended junior college or graduated high school but went straight to the work force?

Tony Affigne, Evelyn Hu-Dehart, and Marilyn Orr's Latino Politics, En Ciencia Politica: the Search for Latino Identity and Racial Consciousness is an edited volume that contains an impressive array of contributions that all use the same data source, the Latino National Survey (LNS). As stated in the introduction to the volume, the LNS is the largest scientific survey done to date that focuses exclusively on Latino respondents. Indeed, "the Latino National Survey has provided a timely and much-needed empirical foundation for understanding a segment of the American population whose continued political incorporation is intimately tied to the future of the country" (2). The importance of the LNS cannot be overstated. Conducted between 2005 and 2008, the survey encompasses nearly ten thousand respondents in twenty states. Participants identify with wide range of backgrounds including Mexican, Cuban, Puerto Rican, Dominican, and Salvadoran. The volume itself serves as a textbook for political science and other social science students. As such every chapter includes a brief introduction from the editors, a summary or key findings, discussion questions, suggestions for further reading, and appendices on how the statistics were used. The LNS offers many opportunities for scholars and the essays in this volume represent 
the tip of the iceberg. Latino Politics makes a major contribution to both political science and Latino Studies by showing the variety of ways the data can be used. The data provide a rich source of current information about Latinos beyond their traditional destinations of the Southwest, Florida, and New York.

One of the most interesting chapters in the book examines the influence of transnational ties on immigrant incorporation into U.S. society via civic participation and naturalization. Stereotypically, immigrants who maintain ties to their countries of origin are thought to be less involved in U.S. society. Authors Sarah Allen Gershon and Adrian D. Pantoja question this assumption in "Latino Immigrant Transnational Ties: Who Has Them, and Why Do They Matter?" The types of transnational ties they examined ranged from following sports teams in the home country, belonging to a home country association, calling relatives, sending remittances, traveling home, and owning property in the home country. The authors found that most immigrants participated in at least three transnational activities, with Dominicans being the most engaged and Cubans the least. Analysis of the data found that transnationalism is "a practice associated with greater stability and resources brought from the home country" and decreases as number of years in the U.S. increases (76). The authors argue that civic engagement with their home country leads to personal and collective empowerment and that although many immigrants to the U.S. are unable to formally participate in the electoral process they "may still impact local and national politics by working with community leaders, groups, and elected officials to solve problems" (79). In other words immigrants' transnational community involvement enhances their leadership skills, allowing them to effect greater change in their new country. This point has clearly been demonstrated through the intense and sustained activism of young immigrants known as DREAMers" and their "Undocumented and Unafraid" campaign. Their political pressure led to President Obama's executive order, Deferred Action for Childhood Arrivals (DACA), which allows for social security numbers and deportation relief for young adults under the age of thirty who were brought to the U.S. as minors and meet certain conditions. DACA was enacted in 2012 and preliminary research shows that the order has increased the economic standing of those who have received this status therefore positively contributing to the overall economy.

One of the provisions of DACA is deportation relief for those who qualify. While this executive order was extraordinary it did not go far enough for DREAMers, who wanted deportation relief for their parents to prevent mixedstatus families from being separated. DREAMers kept up the pressure through a Twitter campaign with the hashtag \#not1more. In the fall of 2014, President Obama announced his newest executive order on immigration, Deferred Action for Parents of Americans (DAPA), which offers deportation relief and a social security number to undocumented immigrants who are parents of minor children. While this action is currently mired in the courts, both DACA and DAPA demonstrate the power of Latino collective action in changing and influencing U.S. society at the highest levels of government. 
This book also makes a significant contribution to Latino political studies. As the editors note, Latinos were not included at all in political science literature before 1970. In a detailed introductory chapter, Tony Affigne shows how the period from 1970-1998 embodied the emergence of Latino political studies, and that 1998 to the present represents a period of empowerment for Latinos in the field of Political Science. The current period encompasses several themes which this volume addresses including political behavior, racial consciousness, identity and social theory, gender and intersectionality, representation and leadership, media, immigration and transnationalism, and political history and social movements (11). As such, the contributors decisively demonstrate that Latinos are more than a one issue political group and that they claim a larger space in the public sphere than is often acknowledged. For example, a recent study showed that on news talk shows Latinos are only represented if the topic is immigration. ${ }^{10} \mathrm{~A}$ twitter hashtag \#askmemás was started in an effort to demonstrate that Latino interests extend beyond this single issue.

Finally, one of the larger questions the book tackles is: Does Latino panethnicity exist? And, if so, what are the processes involved in developing a panethnic latinidad? Some of the more interesting findings include that Latino issues differ by region. For example, Marion Orr, Domingo Morel, and Katrina Gamble studied black and Latino interests in New England and found that rather than engaging in competition, Latinos found more commonality between themselves and African Americans. In contrast, Matt Barreto and Gabriel R. Sanchez discovered a "southern exception" in Black-Latino attitudes towards one another. They hypothesized that "the unique cultural dynamics associated with the South as well as the recent Latino influx may heighten real and perceived competition among Latinos and African Americans" (210). They found that while Latinos in the South do have higher perceived rates of competition with African Americans, the rates of perceived competition with other Latinos are even higher. So while Latinos experience many factors that lead to the development of a panethnic identity, differences between groups exist as well.

The wide range of excellent studies discussed in this review essay demonstrates that across time and in different places, Latinos have influenced U.S. culture by claiming public space for themselves and in many cases invoking a panethnic Latinidad. These works represent how diverse Latino Studies has become. Scholars and students can learn how Latinos influenced the American holiday calendar, religion in the U.S., and how they are making political statements across a broad spectrum due to their growing numbers. Each of these titles brings a fresh perspective to the field - with Torres's showcasing of previously overlooked groups such as women and Mexicans and Mexican Americans living outside the Southwest, Garcia's discussion of the Latino Generation, and HayesBautista's, Matovina's, and Affigne, Hu-Dehart, and Orr's focus on transnationalism. These works demonstrate diversity in the field of Latino Studies and also point to future promise for the field. For example, directions for future research include the creation and dissemination of other festivals such as the Puerto Rican 
Day Parade in New York or the Calle Ocho festival in Miami. Lapsed Latino Catholics or evangelicals of Protestant denominations present other avenues for future research, as does the continued study of Latinos outside of traditional receiving areas. Finally, as an overwhelmingly young group, Latinos promise to exert growing influence in all arenas of American life from popular culture to politics. It remains to be seen whether or not this panethnic Latinidad will hold true over time.

\section{Notes}

1. U.S. Census Bureau, "The Hispanic Population: 2010," by Sharon R. Ennis, Merarys RíosVargas, and Nora G. Albert, May 2011, http://www.census.gov/prod/cen2010/briefs/c2010br-04.pdf (accessed June 8, 2015).

2. Our Lady of Guadalupe is the patroness of Mexico and devotion to her has transferred to the U.S. where many churches are named in her honor.

3. Elizabeth Dias, "The Rise of Evangélicos," Time, April 4, 2013, http://nation.time. com/2013/04/04/the-rise-of-evangelicos/ (accessed June 8, 2015).

4. Elizabeth Dias, "Why 1 in 4 Latinos Now Identify as Former Catholics," Time, May 7 , 2014, http://time.com/89646/why-one-in-four-u-s-latinos-now-identify-as-former-catholics/ (accessed June 8, 2015).

5. Jillian Berman, "Target Turns to Hispanic Shoppers for Salvation," Huffington Post Business, March 6, 2015, http://www.huffingtonpost.com/2015/03/05/target-hispanics_n_6810794.html (accessed June 12, 2015).

6. DACA (Deferred Action for Childhood Arrivals) went into effect in January 2012 and DAPA (Deferred Action for Parents of Americans) was announced in the fall of 2014 and is currently mired in court proceedings.

7. See Marisol Clark-Ibáñez, "DREAMer Activism: Challenges and Opportunities," in Undocumented Latino Youth: Navigating Their Worlds (Boulder, CO: Lynne Rienner Publishers, 2015), 163-78.

8. For a fascinating discussion of the leaky educational pipeline with regard to undocumented Latino immigrants see Marisol Clark-Ibáñez, Undocumented Latino Youth.

9. DREAMers take their name from the 2001 Senate Bill known as the Development, Relief and Education for Alien Minors Act, known as the DREAM Act.

10. Suzanne Gamboa, "Report: Few Latinos on News Shows, Usually to Discuss Immigration," NBC News, March 4, 2015, http://www.nbcnews.com/news/latino/report-few-latinos-newsshows-usually-discuss-immigration-n316396; (accessed March 18, 2015). 